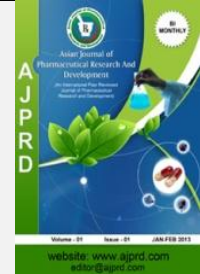

\title{
Histopathological Effects of Potassium Bromate on Liver Male Rat's and Possible Protective Role of Ruta chalepensis L. (Rutacae) Oil Extract
}

\author{
Ebtesam M. M. Gheth, Ibrahim S. Eldurssi, Abdullah A. H. Algassi, Gasem M. A. \\ Abdalla and Mabroka A. S. Hamad
}

Zoology Department, Science Faculty, Omar Al-mukhtar University, El-Beida-Libya,P.O.BOX 919 - ElBeida-Libya

\begin{abstract}
A B S T R A C T
Potassium bromate $\left(\mathrm{KBrO}_{3}\right)$ is an oxidizing agent that has been used as a food additive, mainly in the bread-making process Ruta chalepensis L. (Family-Rutaceae) is a small shrub, native to the Mediterranean Basin. The present study aimed to investigate the protective and curative effects of $R$. chalepensis oil extract against $\mathrm{KBrO}_{3}$ toxicity on liver of male rats. Fifty male albino rats were divided into five groups. The first group served as a control group. The second group was administered Rue at an oral daily dose of $0.5 \mathrm{~g} /$ Animal for four weeks. The third group received $\mathrm{KBrO}_{3} 100 \mathrm{mg} / \mathrm{kg} / \mathrm{b}$. w. for four weeks. The fourth group (protective group) was initially administered Rue alone for 2 weeks and followed by $\mathrm{KBrO}_{3}$ in association with Rue for 2 weeks. The fifth group (therapeutic group) was first given $\mathrm{KBrO}_{3}$ alone for 2 weeks and was then administered Rue in association with $\mathrm{KBrO}_{3}$ for 2 weeks. At the end of $2^{\text {nd }}$ and $4^{\text {th }}$ weeks of treatment, the liver tissues were dissected out for histopathological studies. Histopathological sections of rats administered with Rue showed the same histological observations as in the liver of control animals. $\mathrm{KBrO}_{3}$ treated rats exhibited marked congestion and dilatation of the blood vessels, the central veins and the portal veins. Additionally, marked infiltrative inflammatory cells were revealed. The occurrence of the cellular necrobiotic lesions and nuclei in these necrotic cells showed pyknosis. They also, showed cellular atrophied and hyaline degeneration of the cytoplasm. Vacuoles of different shapes and sizes were developed in the hepatocytes. Blood vessels being thick walled and fibrotic encircled by an inflammatory area rich in leucocytes. The protective and therapeutic groups showed marked hepatoprotective activity and better improvement than that noticed in the group which was given $\mathrm{KBrO}_{3}$ only. It may be concluded from the results that the hepatotoxic effect of $\mathrm{KBrO}_{3}$ and the ameliorative effect of Rue an effective when administrated as protective and therapeutic measures.
\end{abstract}

Keywords: Rat, Liver, Potassium Bromate, Ruta chalepensis, Histopathology.

A R T I C L E I N F 0: Received 11 Jan 2019; Review Completed 29 March 2019; Accepted 11 April 2019; Available online 15 April 2019

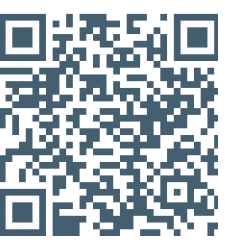

Cite this article as:

Ebtesam M. M. Gheth, Ibrahim S. Eldurssi, Abdullah A. H. Algassi, Gasem M. A. Abdalla and Mabroka A. S. Hamad, Histopathological Effects of Potassium Bromate on Liver Male Rat's and Possible Protective Role of Ruta chalepensis L. (Rutacae) Oil Extract, Asian Journal of Pharmaceutical Research and Development. 2019; 7(2):93-97 DOI: http://dx.doi.org/10.22270/ajprd.v7i2.473

*Address for Correspondence:

Ebtesam M. M. Gheth, Zoology Department, Science Faculty, Omar Al-mukhtar University, El-Beida-Libya P.O.BOX 919 - El-Beida-Libya

\section{INTRODUCTION}

$\mathrm{P}$ otassium bromate $\left(\mathrm{KBrO}_{3}\right)$ is a strong oxidizing agent that has been used in flour milling, as an ingredient in fish-paste in Japan, in cheese making, in beer malting and as a component of cold hair-wave liquids and a oxidizing compound. The toxic or lethal dose of $\mathrm{KBrO}_{3}$ in humans has not been accurately established ${ }^{1}$. Administration of $\mathrm{KBrO}_{3}$ to rats was found to induce oxidative stress and passively impair the antioxidant power of rat blood ${ }^{2,3}$ reported that $\mathrm{KBrO}_{3}$ caused congestion of the central vein with blood cells in the hepatocytes, infiltration of the interstitial cells ${ }^{4}$. indicated that $\mathrm{KBrO}_{3}$ caused vacuolation, neuronal degeneration and haemorrhage. ${ }^{5}$ Showed hepatocyte degeneration and necrosis in liver, congestion and swelling of tubular cells in goats treated with $90 \mathrm{mg} / \mathrm{kg} \mathrm{b}$. w. $\mathrm{KBrO}_{3}{ }^{6}$. reported that $\mathrm{KBrO}_{3}$ caused degeneration, cellular infiltration and significant increase in collagen deposition in portal tracts with a significant increase in immunoexpression of GFAP.

Ruta chalepensis has been medicinally used in many ancient cultures ${ }^{7}$ ). Pharmacological investigations clearly 
indicated that the ethanol extract of the aerial part of $R$. chalepensis shares the anti-inflammatory properties .Toxicity studies have provided basic information about the possible safe use of Ruta ${ }^{8}$. Histopathology of paw tissue showed decreased oedema formation and cellular infiltration on supplementation with MER. Thus, the results demonstrated the potential beneficiary effect of methanolic extract of Ruta graveolens on adjuvant induced arthritis in rats ${ }^{9,10}$. studied 56 patients with colorectal cancer (34 with early stage and 22 with advanced stage) where $R$. chalepensis was found to protect erythrocytes from oxidative stress caused by radicals. This result was noticed in patients with early-stage colorectal cancer and was not observed with advanced disease.

Thus, the aim of this study is to investigate the protective and therapeutic effects of Ruta chalepensis against $\mathrm{KBrO}_{3}$ toxicity on liver of male rats.

\section{MATERIALS AND METHODS}

Fifty male albino rats (Rattus norvegicus), weighing between 275-300 g. were used throughout the present study. They were obtained from the animal house of Zoology Department, Faculty Science, Omar Al-Mukhtar University. The animals were housed in groups of five in standardized cages and were located in the same room with constant environmental conditions such as temperature $\left(22 \pm 3^{\circ} \mathrm{C}\right)$ and humidity $(50-60 \%)$. They were supplied with enough rat feed and drinking water ad-libitum. All animals were allowed to acclimatize in the environment for two weeks before the commencement of the study which lasted for four weeks.

\section{Chemicals used in this study were as follows:}

Potassium bromate $\left(\mathrm{KBrO}_{3}\right)$ : Potassium bromate with the empirical formula $\left(\mathrm{KBrO}_{3}\right)$ obtained from $(\mathrm{BDH})$ company (England).

Rue (Ruta chalepensis L): Leaves of R. chalepensis were collected from Al-Jabal Al-Akhdar region on the east coast of Libya during the period of March 2016. The extraction process for the rue essential oil followed the methodology described by ${ }^{11}$.

Preparation of potassium bromate: Potassium bromate was orally administrated at a dose $100 \mathrm{mg} / \mathrm{kg} / \mathrm{b}$. w. dissolved in distilled water freshly prepared ${ }^{12}$ daily for 2 and 4 weeks according to the group distribution.

Preparation of Ruta chalepensis: The collected flowers and leaves were weighed and washed with water dried and then placed in acetone inside sealed jars for $48 \mathrm{hrs}$. Solvent was removed from samples by rotary evaporator and then oils were collected. $R$. chalepensis was orally administrated at dose of $0.5 \mathrm{~g} /$ Animal $^{13}$, daily for 2 and 4 weeks, which represents the overall experimental duration.
Both doses were orally given through a special stomach tube with a smooth tip to protect the interior lining of the oral and buccal cavity from injury.

\section{Experimental animals grouping:}

The animals were divided into 5 equal groups, each contains 10 male rats: 1) Control Group (G1): Animals of this group received distilled water daily by oral gavage for four weeks. 2) The Rue Treated Group (G2): Rats received Rue orally in a daily dose of $(0.5 \mathrm{~g} /$ Animal $)$, for four weeks. 3) The (KBrO 3$)$-Treated Group (G3): This group included rats that were administrated $\left(\mathrm{KBrO}_{3}\right)$ in a daily dose of (100 mg/kg b. w.) for four weeks. 4) The Protected Group (G4): Animals of this group were first administrated $\mathbf{R} \boldsymbol{u} \boldsymbol{e}$ orally in a dose of (0.5 g/Animal) daily for two weeks and secondly administrated daily oral doses of Rue (0.5 g/Animal) in association with $\left(\mathbf{K B r O}_{3}\right) \quad(100 \mathrm{mg} / \mathrm{kg} \mathrm{b}$. w.) for an additional two weeks. 5) The Therapeutic Group (G5): Animals of this group were first provided with oral dose of $\left(\mathrm{KBrO}_{3}\right)(100 \mathrm{mg} / \mathrm{kg}$ b. w.) daily for two weeks, then were treated orally with $\left(\mathbf{K B r O}_{3}\right)(100 \mathrm{mg} / \mathrm{kg} \mathrm{b}$. w.) in association with Rue $(0.5$ $\mathrm{g} /$ Animal) for an additional two weeks.

\section{Preparation of tissue samples:}

At the end of experiment, animals from control and treated groups were sacrificed $24 \mathrm{~h}$ after the last dose of different administrations and the abdominal cavities were opened and then livers were rapidly excised, washed in saline to remove blood and other extraneous and dried on filter paper. Finally, samples of liver were kept in $10 \%$ neutral buffered formalin solution ${ }^{14}$ (Lillie, 1954) for histopathological examination.

\section{Histopathology:}

Liver specimens were dehydrated in ascending grades of ethyl alcohol (70 \%, $90 \%$ and $100 \%)$, cleared in xylene and impregnated and embedded in paraffin wax. Serial sections of 4-5 micrometers thick were obtained using a rotary microtome and stained with Harris's Haematoxylin and Eosin stain ${ }^{15}$ (Harris, 1900) for general histological examination.

\section{RESULTS}

In group 2, no histological differences were observed between the liver of rats administrated with Rue and those of controls at 2 and 4 weeks of experimental duration (Figures 1 and 2). In group 3, specimens of rats administrated $\mathrm{KBrO}_{3}$ for 2 weeks revealed dilatation and congestion of hepatic sinusoids. Area of vacuolar necrosis and swelling in some hepatocytes, and hyaline degeneration of paranchymal cell with narrowing of blood sinusoids in between were also observed. Some cells showed dark pyknotic eccentric nuclei, others appear with karyolytic nuclei (Figure 3). The portal tract area illustrated in figure (4) designates infiltration with inflammatory cells and vacuolar necrosis throughout 
hepatic lobule in addition to degenerated hepatocytes with indistinct cell boundaries and pyknotic nuclei. Progressive and more pronounced histopathological abnormalities were observed in rats treated with $\mathrm{KBrO}_{3}$ after 4 weeks, including dilated central vein (Figure 5) with erythrocytic congestion. Degeneration and necrosis with nuclear pyknosis and karyolysis were prominent. In the same treated specimens severe hepatotoxicity was observed (Figure 6) as shown by the dissolution of hepatic cords as no liver cords could be followed which appeared as empty vacuoles ballooning degeneration of the hepatocytes and severe necrosis with disappearance of nuclei within lobules, nuclear pyknosis and karyolysis. In group 4, no pathological changes could be noticed in liver treated with Rue alone for 2 weeks. Rue in the protective group that was treated for 2 weeks followed by double treatment with Rue and $\mathrm{KBrO}_{3}$ for another 2 weeks and scarified after 4 weeks, showed marked hepatoprotective activity and better improvement than that noticed in the group which was given $\mathrm{KBrO}_{3}$ only (Figure 7). In group 5, liver sections of rats administered of $\mathrm{KBrO}_{3}$ for 2 weeks revealed different alterations in comparison with control. Histological features of hepatic parenchyma were variable in different parts. These alterations are similar to those of group 3 after 2 weeks (Figures 3 and 4). In this group, good recovery was observed with Rue therapy at the end of the experimentation. Liver sections of rat liver of therapeutic group treated with $\mathrm{KBrO}_{3}$ for 2 weeks then followed by double treatment with $\mathrm{KBrO}_{3}$ and Rue for another 2 weeks and scarified after 4 weeks showed minor focal areas of hyaline degeneration, some necrotic areas and mild walled fibrotic stroma around portal vein (Figure 8).

\section{DISCUSSION}

$\mathrm{KBrO}_{3}$ is a very powerful oxidizer used as flour improver, strengthening the dough and allowing higher rising. It is an oxidizing agent, and under the right conditions, will be completely used up in the baking bread. However, if too much is used, or the bread is not cooked long enough or at a high enough temperature, then a residual amount will remain ${ }^{16}$.

Ruta species are sources of different classes of natural products with biological activities, including antifungal, antioxidant, phytotoxic, abortive depressant, antidotal and anti-inflammatory activities ${ }^{17}$.

Administration of Rue alone after 2 and 4 weeks showed normal liver tissue and normal architecture of hepatic lobules almost similar to that demonstrated by the control group. Rue is known to be relatively nontoxic even when given as an ethanolic or aqueous extracts of seeds at a dose of $R$. graveolens $50 \mathrm{mg} / \mathrm{kg} /$ day via the oral route ${ }^{18}$. But when given at dose $200 \mathrm{mg} / \mathrm{kg} /$ day via the oral route, it caused fatty cytoplasmic vacuolation of the centrilobular hepatocytes and isolated cell necrosis and hemorrhage.
The pathological responses of the liver tissues to $\mathbf{K B r O}_{3}$ observed in this study were in agreement with that reported by ${ }^{19}$ who mentioned $\mathrm{KBrO}_{3}$ caused fatty cytoplasmic vacuolation or focal necrosis of the centrilobular hepatocytes of rats. $\mathrm{KBrO}_{3}$ caused congestion of the central vein and sinusoidal dilatation as well as cell necrosis. This result is similar to that obtained by $^{20,21,5}$ who reported the hepatocyte degeneration and necrosis in liver, congestion and swelling of tubular cells, as well as congestion and dilation of portal veins. The dilation of these veins observed in the present work is in accord with those presented by ${ }^{22}$ who mentioned severe dilation of the central veins. Vacuolation and sinusoidal dilatation of liver cells have been previously associated with reduction of antioxidant enzymes and enhancement of xanthine oxidase and lipid peroxidase by $\mathrm{KBrO}_{3}{ }^{20}$. Degenerative changes and fenestration of endothelial cells in rats administered of $\mathrm{KBrO}_{3}$, may be an indication of the destruction of the capillary endothelium of the liver by the chemical substance ${ }^{20}$. Necrosis is evidenced by nuclear disintegration and increased eosinophilic reaction of the cytoplasm. The nuclei in these dying cells showed pyknosis and karyolysis. Necrosis may be restricted to a small group of cells, producing necrotic foci; central, midzonal or periportal, or it may be a massive one ${ }^{23}$. The presence of necrosis may also be related to the depletion of ATP, which finally leads to the death of the cells ${ }^{24}$. Fibrosis was also observed as a result of $\mathrm{KBrO}_{3}$ administration to the rats. Liver fibrosis is a catabolic feature associated with protein breakdown ${ }^{25}$. There are various possible sources of collagen formation in the liver including; hepatocytes, fibroblasts, myofibroblasts and biliary epithelial cells ${ }^{26}$. This study revealed that the ingestion of $\mathrm{KBrO}_{3}$ was deleterious causing degeneration and vacuolation. These results were in accordance with that reported by who studied the histopathological changes on rat liver and kidney fed with MSG contaminated food. In the current work, hyaline degeneration of the cytoplasm was shown and illustrated after 2 and 4 weeks. Administration of MSG initially attacked the peripheral hepatocytes in the central lobules of the liver tissues leading to hepatocellular degeneration $^{27}$.

In the protective group, the histopathological findings revealed marked hepatoprotective effects of Rue extract in $\mathrm{KBrO}_{3}$-induced liver damage, probably due to the antioxidant effect of Rue. This result is similar to the findings of ${ }^{28,29}$. R. chalpensis extracts possess potent antioxidant activities, which could be derived from compounds such as flavonoids and polyphenols. $R$. chalpensis extracts could give rise to antimicrobial, antiinflammatory and antiulcer agents and could be promising candidates for further studies designed to obtain more evidence on their components with potential chemopreventive activity $^{30}$ 


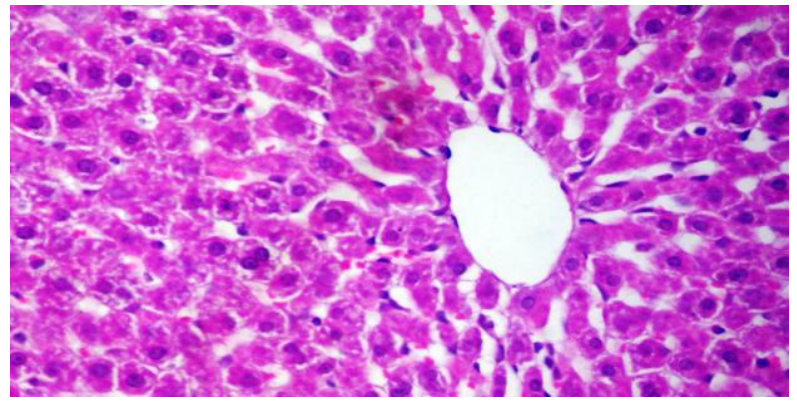

Figure (1): Photomicrograph of a section from control rat liver ( $\mathrm{H} \& \mathrm{E}, \mathrm{X} 400)$.

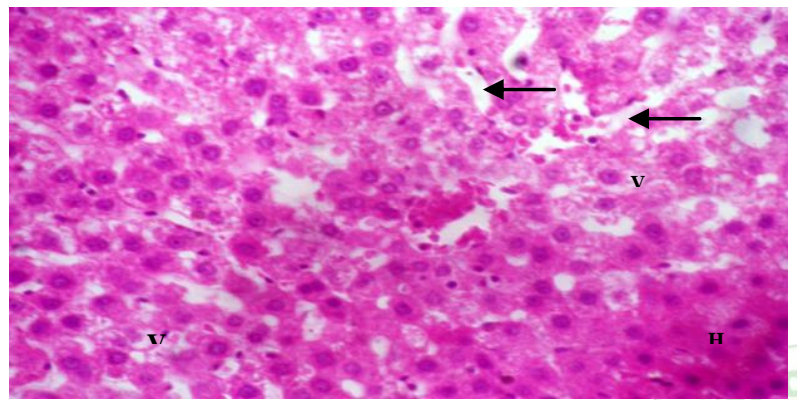

Figure (3): Photomicrograph of a section in liver of rat treated daily with $\mathrm{KBrO}_{3}(100 \mathrm{mg} / \mathrm{kg})$ for 2 weeks showing dilated sinusoide (arrow) and hyline degeneration of paranchymal cells $(\mathrm{H})$. Area of vacuolar necrosis throughout hepatic lobule (V) (H\&E, X 400).

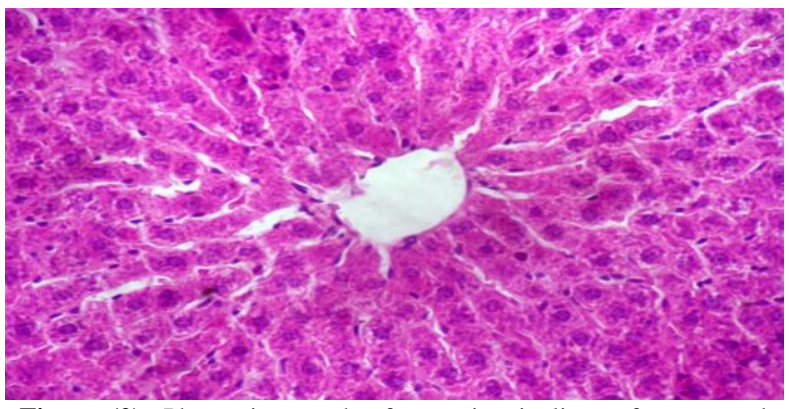

Figure (2): Photomicrograph of a section in liver of rat treated daily with Rue $(0.5 \mathrm{~g} /$ Animal) for 4 weeks showing normal hepatic pattern of central vein, blood sinusoids and normal orderly arrangement of hepatocytes. No histopathological changes were detected (H \& E, X 400).

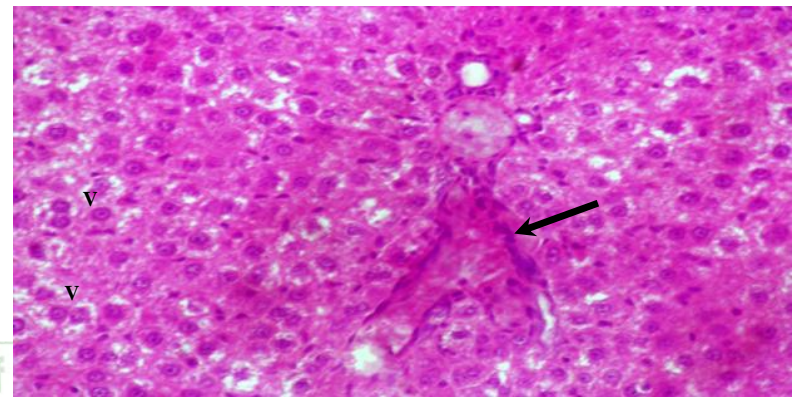

Figures (4): Photomicrographs of sections in liver of rats treated daily with $\mathrm{KBrO}_{3}(100 \mathrm{mg} / \mathrm{kg})$ for 2 weeks showing portal infiltrated with inflammatory cells (arrow) and hepatocyte vacuolization (V) (H\&E, X 400).

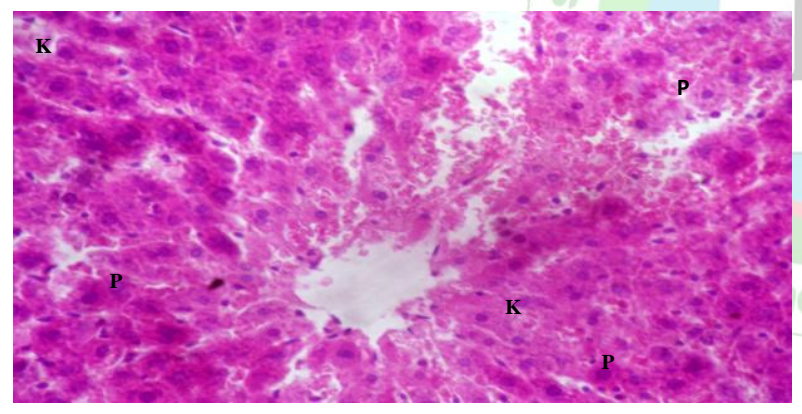

Figure (5): Photomicrograph of a section in liver of rat treated daily with $\mathrm{KBrO}_{3}(100 \mathrm{mg} / \mathrm{kg})$ for 4 weeks showing dilated central vein with erythrocytic congestion surrounded by necrotic with nuclear pyknosis $(\mathrm{P})$ and karyolysis $(\mathrm{K})(\mathrm{H} \&$ E, X 400).

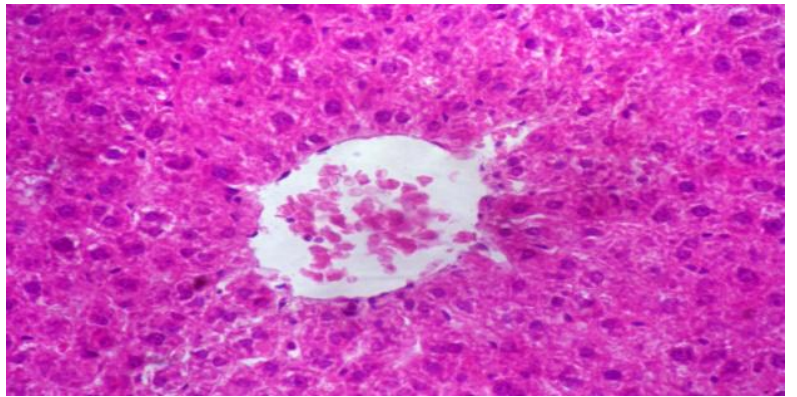

Figure (7): A photomicrograph of the liver of rat from protective group after 4 weeks showing normal hepatic pattern of central vein with mild focal area of necrosis in paranchymal cells, and some of which lost their membrane boundaries from neighboring cells (H\&E, X 400).

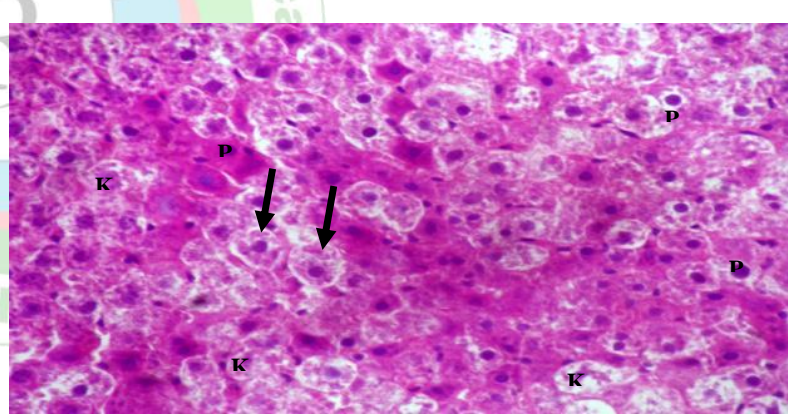

Figure (6): Photomicrograph of a section in liver of rat treated daily with $\mathrm{KBrO}_{3}(100 \mathrm{mg} / \mathrm{kg})$ for 4 weeks showing ballooning degeneration of hepatocytes (arrows) and areas of parenchymal necrosis with nuclear pyknosis (P) and karyolysis (K). The cell boundaries were lost with distortion of the normal hepatic architecture (H \& E, X 400).

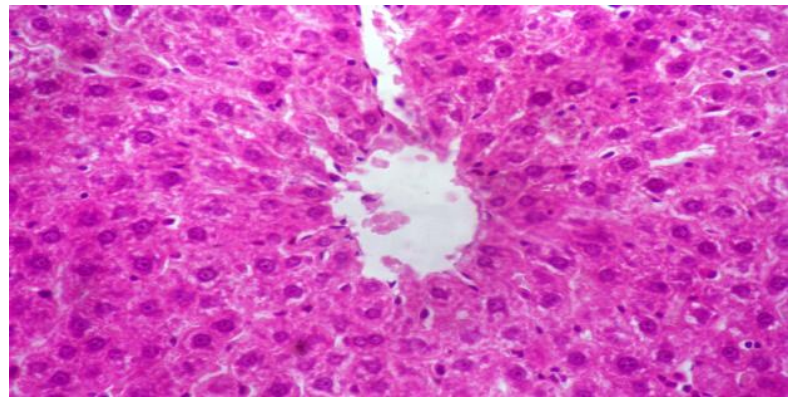

Figure (8): Photomicrographs of sections in liver of rats from therapeutic group after 4 weeks showing sign of recovery in the central vein and hepatocytes $(\mathrm{H} \& \mathrm{E}, \mathrm{X}$ 400). 
In the curative group, there is mild improvement as a result of Rue administration where moderate destruction of lobular structurewas observed. Histological features of hepatic parenchyma were variable in different parts. These alterations were manifested in disorganization of the hepatic structure and mild hyline degeneration, hemorrhage, degenerated hepatocytes with indistinct cell boundaries and the nuclei appearance, either eccentric and pyknotic or lost completely, were also observed during the first 2 weeks of $\mathrm{KBrO}_{3}$ administration. Thereafter, by the end of experimental period, Rue extract in the curative group was found to be less effective in restoring $\mathrm{KBrO}_{3}$ induced histopathological alterations.

Evidently, histopathological examinations of liver also did not support Rue therapy as it did not help in improving cellular architecture. This appearance indicates poor treatment of the hepatocytes against the hepatotoxic agent. Nevertheless, the present study confirms that Rue has some protective effect against the hepatotoxic agent $\mathrm{KBrO}_{3}$; yet the obtained results could not prove their effectiveness as therapeutic agents. No significant results were obtained from the use of Rue indicating only minimal therapeutic effect for the liver. The present findings do not find strong support from previous researches, thus this study is to be considered as the first study on the protective and therapeutic effects of Rue against $\mathrm{KBrO}_{3}$.

\section{CONCLUSION}

In conclusion, the results of this study confirm the hepatotoxic effect of $\mathrm{KBrO}_{3}$ and the ameliorative effect of Rue when administrated as protective and therapeutic measures.

\section{ACKNOWLEDGEMENT}

Special thanks to Dr. Hoda Khatab and Dr. Nagat S. ELhaddad in Botany Department, Science Faculty, Omar Al-Mukhtar University for hers help in extraction of plant in this study.

\section{REFERENCES}

1. Kurokawa Y, Mackawa A, Takahashi N, Hayeshi Y,Toxicity and carcinogenicity of potassium bromate - a new renal carcinogen. Environ. Health Perspect, 1990; 87:309-355.

2. Ahmad MK, Mahmood R, Oral administration of potassium bromate, a major water disinfection by-product, induces oxidative stress and impairs the antioxidant power of rat blood. Chemosphere, 2012; 87(7):750-756.

3. Akanji MA, Nafiu M O, Yakubu MT, Enzyme activities and histopathology of selected tissues in rats treated with potassium bromate. Afr. J. Biomed. Res, 2018; 11:87-95.

4. Abuelgasim A, Omer R, Elmahdi B, Serrobiochemical Effects of Potassium Bromate on Wistar Albino Rats. Am. J. Food Technol., 2008; 3:303-309.

5. Gibreel HM, (2008). Toxicity of Potassium Bromate to Nubian Goat Kids. $M V S c$. Thesis, Faculty of Veterinary Medicine, University of Khartoum

6. Bayomy NA, Soliman GM, Abdelaziz, EZ, Effect of Potassium Bromate on the Liver of Adult Male Albino Rat and A Possible Protective Role of Vitamin C: Histological, Immunohistochemical, and Biochemical Study. Anat. Rec., 2016; 299:12560-1269.

7. Kong YC, Ng KH, Wat KH, Wong A, Saxena IF, Cheng KF, But PP, Chang HT, Yuehchukene, a Novel Anti-implantation Indole Alkaloid from Murraya paniculata. Planta Med, 1985; 51(4):304307.
8. Shah AH, Qureshi S, Ageel AM, Toxicity studies in mice of ethanol extracts of Foeniculum vulgare fruit and Ruta chalepensis aerial parts, J. Ethnopharmacol,1991; 34:167-172.

9. Ratheesh M, Shyni GL, Helen A, Methanolic extract of Ruta graveolens L. inhibits inflammation and oxidative stress in adjuvant induced model of arthritis in rats. Inflammopharmacol,2009; 17(2):100-105.

10. Acquaviva R, Iauk L, Sorrenti V, Lanteri R, Santangelo R, Licata A, Licata F, Vanella A, Malaguarnera M, Ragusa S, Di Giacomo C, Oxidative profile in patients with colon cancer: effects of Ruta chalepensis L. Eur. Rev. Med. Pharmacol. Sci., 2011; 15(2):181191.

11. Kanadea R, Bhatkhandeb DS, Extraction of ginger oil using different methods and effect of solvents, time, temperature to maximize yield. Inter. J. Adv. Sci. Eng. Technol., 2016; 4(2):241244.

12. Ukoha UU, Umeasalugo KE, Okafor J I, Udemezue OO, Ndukwe GU, Udenwogu CJ, (2014). The Histological Effect of Potassium Bromate on the Cerebellum of Adult Wistar Rats. Inter. J. Health Sci. Res., 2014; 4(9):114-118.

13. Al Qarawi AA, Stimulatory Effect of the Aqueous Extract of Ruta chalepensis on the Sex Organs and Hormones of Male Rats. $J$. Appl. Res., 2005; 5(1):206-211.

14. Lillie RD, (1954). Histopathological Techniques and Practical Histochemistry, McGraw-Hill, U.S. A

15. Harris HF, (1900). After Bruce Casselman W. C. (1959). Histochemical Technique, by Methuen and Co. Ltd.

16. Fujii M, Oikawa K, Saito H, Fukuhara C, Onosaka S, Tanaka T, Metabolism of potassium bromate in rats II. In vitro studies. Chemosphere 1984; 13(11):1213-1219.

17. Raghav SK, Gupta B, Agrawal C, Goswami K, Das HR, Antiinflammatory effect of Ruta graveolens L. in murine macrophage cells. J. Ethnopharmacol., 2006; 104(1-2):234-239.

18. Adam Sh IY, Ahmed NN A, Eltayeb AM, Saad H, Taha KA Toxicity of Ruta graveolens Seeds' Extracts on Male Wistar Rats. Int. J. Anim. Veter. Adv., 2014; 6(3):92-96.

19. Abdel Gadir, EH, Abdel Gadir, WS, Adam SEI, Effects of Various Levels of Dietary Potassium Bromate on Wistar Rats. $J$ Pharmacol. Toxicol., 2007; 2(7):672-676.

20. Abuelgasim A, Omer R, Elmahdi B, Serrobiochemical Effects of Potassium Bromate on Wistar Albino Rats. Am. J. Food Technol., 2008; 3:303-309.

21. Oyewo OO, Onyije FM, Awoniran PO, Hepatotoxic effect of potassium bromate on the liver of wistar rats. J. Morphol. Sci. 2013; 30(2):107-114

22. El-Sherif FG, Gobri MS, Zahran WM, Abdel-Hamid TF Histological, histochemical studies and ATP-ase localization in the rat liver after morphine sulphates induction. J. Egypt. Ger. Soc. Zool.,2002; 39:175-187.

23. Cotran, RS, Kumar V, Collins T, (1999). The Liver and the Biliary Tract. In: Pathologic Basis of Disease. $6^{\text {th }}$ ed., London, W. B Saunders, pp.: 846-901.

24. Shimizu, S., Eguchi, Y., Kamiike, W., Waguri, S., Uchiyama, Y., Matsuda, H. and Tsujimoto, Y. (1996). Retardation of chemical hypoxia induced necrotic cell death by $\mathrm{Bcl}-2$ and ICE inhibitors: Possible involvement of common mediators in apoptotic and necrotic signal transductions. Oncogene., 12: 2045-2050.

25. Tavill, AS, Intracellular pathways of protein synthesis and secretion in the hepatocytes. Semin Liver Dis., 1985; 5:95-109.

26. Phillips, MI, Poucell S, Patterson J, Valencia P, (1987). The liver. An Atlas and Text of Ultrastructural Pathology. Raven Press, New York, p. 398.

27. Bopanna, KN, Balaraman R, Nadig RS,. Organotropic ultrastructural changes produced by monosodium glutamate in rats on Atherogenic diet: effect of S-allyl cysteine sulphoxide. Ind. J. Pharmacol., 1999; 31(4):266-274.

28. ElAgouza, IMA, El Nashar, DE,Eissa S.S, The possible ultra structural ameliorative effect of taurine in rat's liver treated with monosodium glutamate (MSG). The Open Hepato. J, 2010; 2:1-9.

29. Ahmad MK, Mahmood R. Oral administration of potassium bromate, a major water disinfection by-product, induces oxidative stress and impairs the antioxidant power of rat blood. Chemosphere, 2012; 87(7): 750-756

30. Ben Sghaier M, Louhichi T, Hakem A, Ammari Y, Chemical investigation of polar extracts from Ruta chalpensis L. growing in Tunisia: Correlation with their antioxidant activities. Agri. Biotech., 2017; 49 (4): 2971-2978. 